\title{
Effect of LPS on the Viability and Proliferation of Human Oral and Esophageal Cancer Cell Lines
}

\author{
Márcia Gonçalves ${ }^{*}$, Ángelica Regina Cappellari ${ }^{1}$, André Avelino dos Santos Junior ${ }^{1}$, \\ Fernanda Olicheski de Marchi ${ }^{1}$, Fernanda Souza Macchi ${ }^{1}$, Krist Helen Antunes ${ }^{2}$, Ana Paula \\ Duarte de Souza ${ }^{2}$, Fernanda Bueno Morrone ${ }^{1}$ \\ ${ }^{I}$ Pontificia Universidade Católica do Rio Grande do Sul, Faculdade de Farmácia, PUCRS, Brasil. ${ }^{2}$ Instituto de \\ Pesquisas Biomédicas;
}

\begin{abstract}
The esophagus and mouth tumors are very frequent malignancies worldwide. Lipopolysaccharides (LPS) are capable of regulating gene expression of pro-inflammatory cytokines by binding to toll-like receptor 4 (TLR4). Recent studies show that LPS can increase the migration ability of human esophageal cancer cell line HKESC-2 by increasing its adhesion properties. However, the effect of LPS has not been tested on viability of human esophageal and oral cancer cells. This study aimed to determine the action of LPS on the cell proliferation and viability in OE19 (adenocarcinoma) and OE21 (squamous carcinoma) cell lines, representative of human esophageal cancer, and HN30 cell line, representative of human oral carcinoma. LPS was used as treatment to OE19 and OE21 cells, and PgLPS (Porphyromonasgingivalis lipopolysaccharide) to HN30 cells. Viability was assessed by MTT assay and proliferation by cell counting. TLR4 expression was evaluated by real-time PCR. LPS at higher concentrations decreased significantly cell viability in both cell lines, adenocarcinoma (OE19) and squamous esophageal carcinoma (OE21) at different times of treatment. In addition, both cell lines, OE19 and OE21, expressed TLR4 receptor. Taken together, our data demonstrated that LPS at high concentrations might contribute to tumor death, in agreement with previously data.
\end{abstract}

Key words: LPS, oral cancer, esophageal cancer, TLR4.

\footnotetext{
*Author for correspondence: mfsonmez@erciyes.edu.tr
} 


\section{INTRODUCTION}

Esophageal cancer is the eighth most common in the world, with more than 480,000 new cases annually, and is responsible for over 400,000 deaths, making it the sixth leading cause of cancer death (Tarapore et al. 2013). Risk factors such as alcohol consumption, smoking, nutritional deficiencies, food, drinking hot liquids and occupational exposure are involved with the development of esophageal tumors (Mota et al. 2013; Thakur et al. 2013). Steffen et al. (2015) demonstrated that abdominal obesity is an indisputable risk factor for esophageal adenocarcinoma (Steffen et al. 2015). The prognosis is low, with a $15 \%$ survival rate at 5 years (Arantes et al. 2012). The two main histological types of esophageal cancer are adenocarcinoma and squamous cell carcinoma, which differ according to their risk factors and demographic distributions (Ma et al. 2012). Although adenocarcinoma was the most common subtype in white men in the United States since the early $90 \mathrm{~s}$, squamous cell carcinoma is still the most prevalent subtype in the world (Almodova et al. 2013; Ren et al. 2013). Esophageal squamous cell carcinoma carries a very poor prognosis because many cases go undetected until the disease is at an advanced stage (Xu et al. 2014).

Mortality from cancer of the oral cavity is high, with recent estimate of 128,000 deaths per year worldwide (Toporcov et al. 2012). Types of oral cancer include malignant tumors of the salivary gland, sarcoma of soft tissue and bone of the jaw, melanoma, malignant odontogenic tumors, lymphoreticular malignancies, metastases and tumors located in any part of the body (Waal 2013). The standard treatments for these cases include surgery and radiation; chemotherapy can be used in advanced cases or as palliative treatment (Romanini et al. 2012; Girardi et al. 2013). Main causes of oral cancer are similar for esophageal cancer (Chen et al. 2013). On the other hand, Increasing appreciation of tumor heterogeneity and the tumor-host interaction has stimulated interest in developing novel therapies that target both tumor cells and tumor microenvironment (Xu et al. 2014). Some authors mention lipopolysaccharides (LPS) as one of these novel therapies as they indicate that the LPS are characteristic compounds of the cell wall of gramnegative bacteria (Yang et al. 2012). In response to systemic exposure of LPS, pro-inflammatory cytokines such as Tumor Necrosis Factor (TNF), interleukin (IL)-1 $\beta$, and interferon- $\gamma$ produced by the host mediate many inflammatory and hemodynamic changes and organ dysfunction in sepsis (Vernooy et al. 2001). LPS are able to regulate gene expression of pro-inflammatory cytokines through activation of toll-like receptor 4 (TLR4) via NF-kB (Yang et al. 2012).

Recently, there has been a growing interest in antitumor functions initiated by the innate immune response. TLRs are type I transmembrane protein with extracellular domains comprised largely of leucine-rich repeats and intracellular signaling domains that play a crucial role in inflammation and host defense against invading microorganisms through the recognition of pathogen-associated molecular patterns such as LPS, lipopeptides, RNA, and bacterial DNA (Sun et al. 2012). Their activated signaling pathways in cancer cells could have profound consequences for tumor growth by promoting cancer progression, anti-apoptotic activity, and resistance to host immune responses (Sun et al. 2012). A study by Paleja et al. (2013) demonstrated that the stimulation of the TLR by various ligands such as LPS and $\mathrm{CpG}$ among others, do not significantly increased tumor cytotoxic response (Paleja et al. 2013).

Of interest, stimulation of TLR4 with LPS could promote the migration and invasion of lung cancer cells (Liu et al. 2015). TLR4 has been implicated in tumor cell invasion, survival, and metastasis in a variety of cancers (Yang et al. 2014). Recent studies show that LPS can increase the migration ability of human cell esophageal cancer HKESC-2 by increasing its binding properties by signaling via TLR4 (Rousseau et al. 2013). In this way, the aim of this study was to determine the action of LPS and PgLPS in cancer cell lines proliferation and viability using human esophagus OE19 and OE21 and the human oral carcinoma HN30. Furthermore, we intend to evaluate the expression of TLR receptor 4 in human esophageal and human oral cancer cell lines.

\section{MATERIAL AND METHODS}

\author{
Reagents \\ LPS and PgLPS were obtained by Invitrogen. \\ Dimethyl sulfoxide (DMSO) was obtained from \\ Sigma Aldrich and culture media Dulbecco's \\ Modified Eagle Medium (DMEM) and RPMI \\ (Roswell Park Memorial Institute), Trypsin and
}


Fetal Bovine Serum (FBS) were obtained from Life Technologies (Gibco).

\section{Cell Culture and Treatments}

The cell lines OE19 (adenocarcinoma) and OE21 (squamous cell carcinoma) and HN30 (oral carcinoma) were obtained through donation of National Cancer Institute (INCA, RJ). They were kept in an incubator at $37^{\circ} \mathrm{C}$ with $5 \% \mathrm{CO}_{2}$ and $95 \%$ humidity. The OE19 and OE21 cell lines were maintained in culture with RPMI 1640 and HN30 with DMEM, both medium supplemented with $10 \%$ FBS, fungizone and antibiotic. The OE19 cell line corresponds to adenocarcinoma of the esophagus, gastroesophageal junction, pathological stage III with moderate differentiation. The OE21 cell line corresponds to squamous cell carcinoma of the middle third of the esophagus, pathological stage IIA, with moderate differentiation. When the cells reached $70-80 \%$ confluence were treated for 24,48 and $72 \mathrm{~h}$ at concentrations of $0.1,1,10,20,50$ and $100 \mu \mathrm{g} / \mathrm{mL}$ of LPS (for OE19 and OE21 cell lines) and at concentrations of $0.1,1,10,20,50$ and $100 \mu \mathrm{g} / \mathrm{mL}$ for PgLPS (only for HN30 cell line).

\section{Cell Viability - MTT Assay}

After treatment, the cell viability was evaluated by MTT (tetrazolium blue thiazol - 3- [4,5-dimethylthiazol-2-yl] - 2,5-diphenyl-tetrazolium) assay. Cells were seeded in 96 well plates with cell density of $5 \times 10^{3}$ cells per well and treated after reach confluence. Cell cycle was synchronized by reduction of the culture medium to $5 \%$ and $0.5 \%$ FBS. The respective culture medium plus $10 \%$ FBS was used as positive control. After 24, 48 and $72 \mathrm{~h}$ of treatment, the experiment of MTT was performed. One hundred (100) $\mu \mathrm{L}$ of a solution containing $90 \%$ medium and $10 \%$ of $5 \mathrm{mg}$ MTT / $\mathrm{mL}$ diluted in PBS (Phosphate Buffered Saline) were added. The cells were then incubated for $3 \mathrm{~h}$ at $37^{\circ} \mathrm{C}$. Follow, MTT solution was discarded and the plate was completely dried, were added $100 \mu \mathrm{L}$ of DMSO in each well. The quantification was done by absorbance spectrophotometer Spectra MaxM2e Soft Max ${ }^{\circledR}$ from Molecular Devices Pro 5 to $492 \mathrm{~nm}$.

\section{Cell Proliferation - Cell Count}

The cell number was evaluated after treatment using a counter (Countess II FL - Life Technologies in). It was held plating of $2 \times 10^{4}$ cells per well in 24-well plates. Cell cycle was synchronized by reduction of the culture medium to $5 \%$ following by $0.5 \%$ FBS. The respective culture medium plus 10\% FBS was used as positive control. The respective culture medium plus $10 \%$ FBS was used as positive control. The experiments were performed after 24, 48 and $72 \mathrm{~h}$ of treatment. The culture medium was discarded and added $100 \mu \mathrm{L}$ Trypsin / EDTA solution (Disodium ethylenediaminetetraacetic acid). Trypan Blue stain was used for counting to exclude non-viable cells. The number of viable cells was determined by perceptual in relation to control.

\section{qRT-PCR Expression}

RNA from treated cells was extracted using RNAeasy kit (Qiagen, EUA). cDNA was obtained using Sensiscript Reverse Transcription kit (Qiagen). Relative Real Time PCR was carried out on the equipment StepOne Real-Time PCR System (Applied Biosystems), with StepOne Software 2.3 program, using primers 20x TaqMan ${ }^{\circledR}$ Experimental Gene Assay, for the targets TLR4 Hs01060206 mL and $\beta$-actin ACTB (20x) 4333762F (Applied Biosystems) as constitutive gene for reaction control. To determine the relative RNA expression levels was used 2- $\Delta \Delta \mathrm{CT}$ method.

\section{Statistical Analysis}

The statistical analysis was performed by one-way analysis of variance (ANOVA), followed by Tukey post-hoc test. Results were presented as the mean \pm standard error of the mean (SEM) and $p$ values smaller than 0.05 were considered significant $(\mathrm{p}<0.05)$.

\section{RESULTS}

LPS is the principal component of Gram negative bacteria that activates the innate immune system. PgLPS is a purified preparation of lipopolysaccharide from the Gram-negative bacteria Porphyromonasgingivalis. Since PgLPS is an important virulence factor in the mechanisms of peridontal disease we chose to test this compound in oral carcinoma (HN30 cell line), and LPS was used to test the esophageal lines.

Firstly, we evaluated LPS effect on esophageal cancer cells viability. The results of the MTT assay shown in Figure 1A demonstrated that LPS, at the higher concentrations of 20,50 and 100 $\mu \mathrm{g} / \mathrm{mL}$, decreased significantly OE19 cell viability 
when compared to control, for all the times tested (24, 48 and $72 \mathrm{~h})$. The effect of LPS on OE21 cells was similar to OE19 cells (Fig. 1B). In contrast, PgLPS treatment in HN30 cells increased the cell viability in relation to control after $48 \mathrm{~h}$ (Fig. 1C), but these results were not significant.
A

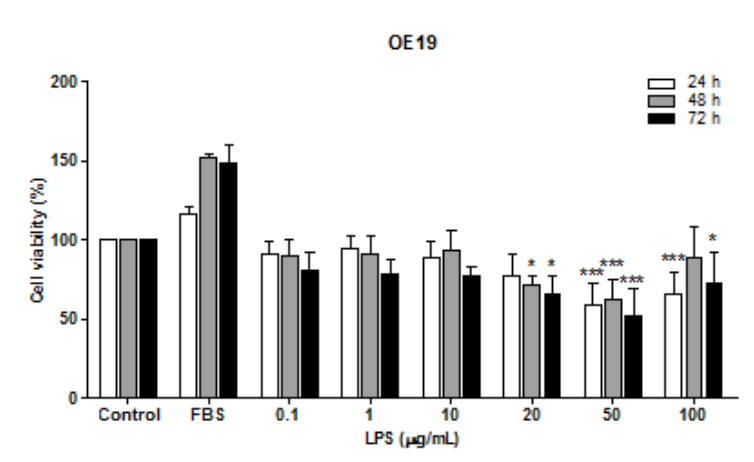

B

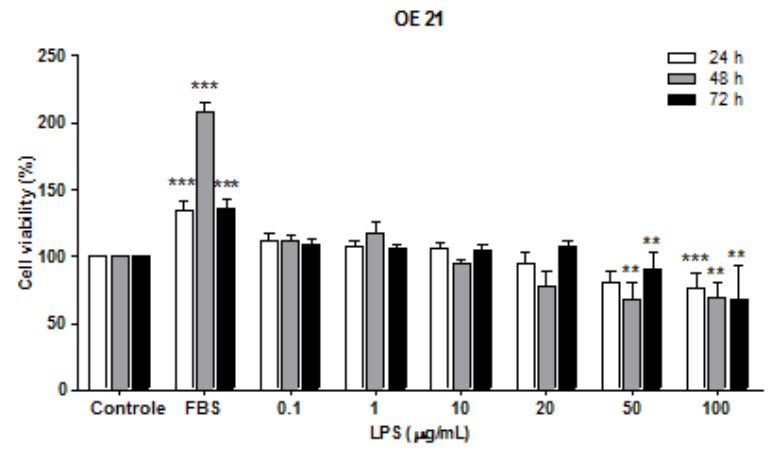

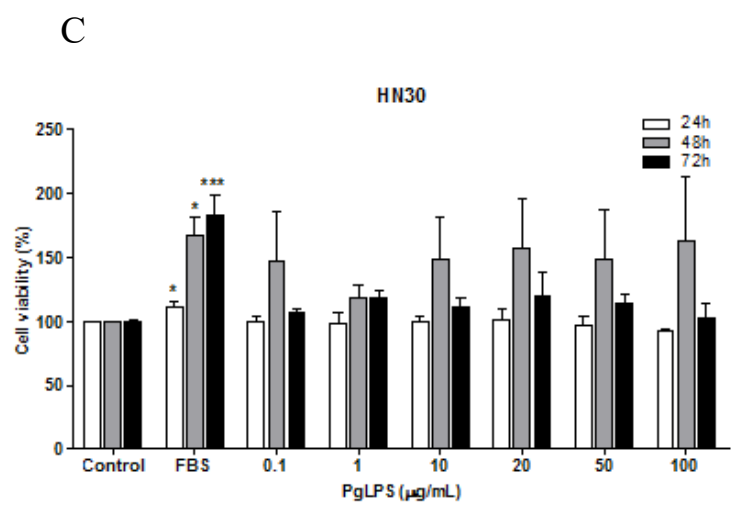

Figure 1- Evaluation of cell viability of OE19 (A), OE21 (B) and HN30 (C) cell lines after 24, 48 and $72 \mathrm{~h}$ of treatment with LPS and PgLPS respectively. The experiments were performed five times in triplicate. Each column represents the mean \pm SEM. ${ }^{*} \mathrm{P}<0.01 ; * * \mathrm{P}<0.01 ;{ }^{* * *} \mathrm{P}<0.001$ for comparison versus control, as determined by ANOVA following by Tukey post-hoc test.

In addition, in order to evaluate the proliferative effect of LPS, we count the cells after treatment. The results shown in Figure 2A, demonstrated that LPS at the higher concentrations (50 and 100 $\mu \mathrm{g} / \mathrm{mL}$ ) decreased significantly OE19 cell number when compared to control, in 48 and $72 \mathrm{~h}$ after treatment. The effect of LPS on squamous esophageal carcinoma cells (OE21 cell line) was quite similar to esophageal adenocarcinoma cells (OE19), presented in Figure 2B. It was observed a significant decrease in cell number when compared to control at higher concentrations of LPS (50 and $100 \mu \mathrm{g} / \mathrm{mL}$ ). The results with oral cancer, HN30 cell line, showed that PgLPS treatment had no effect on cell number, although there was a tendency to increase the cell viability at $48 \mathrm{~h}$ treatment (Fig. 2C). Overall, our results demonstrated that LPS present a distinct effect on cell proliferation and viability depending on the concentration used. 
A

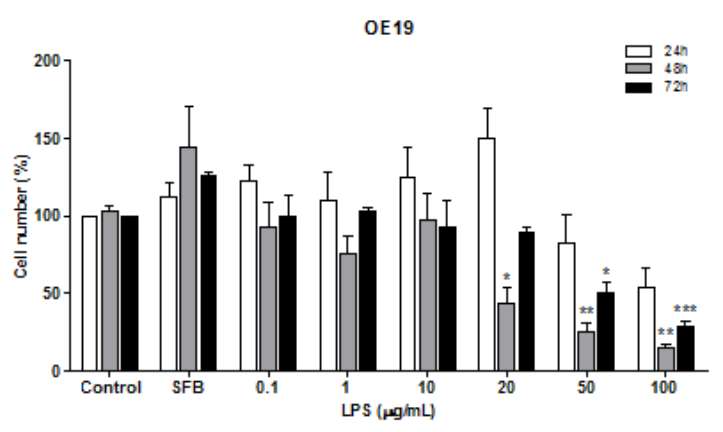

$\mathrm{B}$

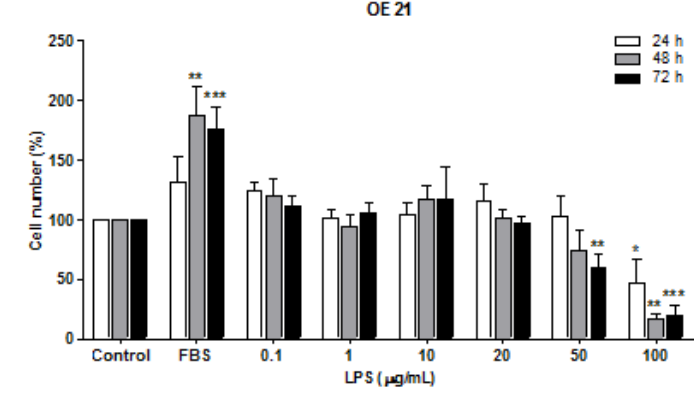

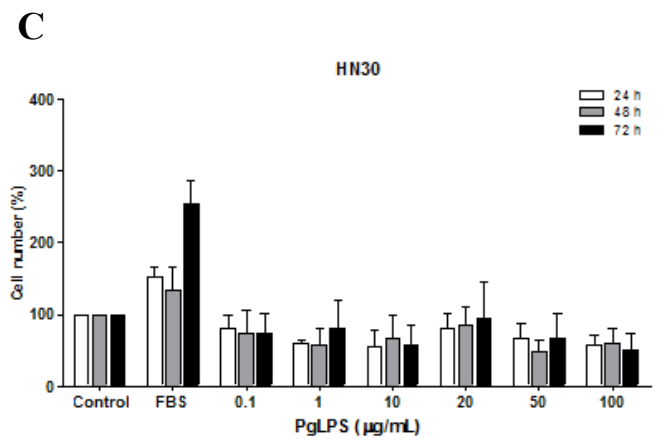

Figure 2-Cell proliferation of OE19 (A), OE21 (B) and HN30 (C) cell lines after 24, 48 and $72 \mathrm{~h}$ of treatment with LPS and PgLPS by cell count assay.The experiments were carried out at least five times in triplicate. Each column represents the mean \pm SEM. ${ }^{*} \mathrm{P}<0.01 ; * * \mathrm{P}<0.01 ; * * * \mathrm{P}<0.001$ for comparison versus control, as determined by ANOVA following by Tukey post-hoc test.

In order to understand the mechanisms involved in LPS compounds effects, we investigated the expression of TLR4 in the OE19 and OE21 cell lines, since the results were significant for just these cell lines in the MTT and cell count assays. The results of qRT-PCR assay showed that esophageal cancer OE19 and OE21 cell lines expressed toll-like receptor TLR4 (Fig. 3A and 3B). Squamous esophageal carcinoma cell line (OE21) showed a higher expression of this receptor when compared to adenocarcinoma cells (OE19).

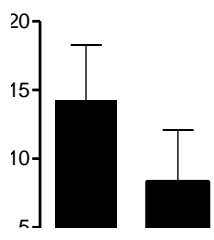

A

Figure 3- Relative expression of TLR4 in cell lines OE21 and OE19 byqRT-PCR: (A) each cell line OE21 and OE19 relative expression and (B) relative expression of OE21 vs OE19.

In this study, we used different cell lines of esophageal carcinoma (OE19 and OE21) and oral cell carcinoma (HN30) to test LPS effect on cell proliferation and survival. OE19 cell line corresponds to adenocarcinoma of the esophagus, gastroesophageal junction, pathological stage III, with moderate differentiation. On the other hand, OE21 cell line corresponds to squamous cell carcinoma of the middle third of the esophagus, pathological stage IIA, with moderate differentiation. Given the different characteristics of the cell lines evaluated, our data demonstrated that LPS treatment decreased significantly cell viability and cell number in the esophageal adenocarcinoma cells (OE19 cell line) in all times of treatment (24, 48 and $72 \mathrm{~h}$ ). In a similar way, treatment with LPS promoted a decrease in cell viability on squamous esophageal carcinoma cells (OE21 cell line) at 24, 48 and $72 \mathrm{~h}$ after treatment. 
This may indicate that cancer cells can be sensitized to bacteria and host-derived ligands, like LPS. In addition, here we demonstrated that both cells (OE21 and OE19) expressed TLR4 and this receptor is up regulated in both squamous cell carcinoma and adenocarcinoma of the esophagus.

Some authors' mention that exposure to LPS can have opposite effects on the adhesion of tumor cells and tumor development. Firstly, by binding to TLR4, LPS induces the production of reactive oxygen species by macrophages, damaging the endothelium and promoting the exposure of the endothelial extracellular matrix, which circulating tumor cells may adhere. Secondly, the LPS can stimulate the clearance of immunogenic tumor cells promoting adaptive immune responses (Gül et al. 2012). In macrophages, LPS induction actives transcription of genes encoding proinflammatory proteins, which leads to the release of cytokines and the synthesis of enzymes such as cyclooxygenase-2 (Niu et al. 2015). Previous study has shown that LPS increases migration and adhesive properties of esophageal squamous carcinoma cells (HKESC-2 and HKESC-1) by TLR4 stimulation via p38 and selectin, contributing to tumor metastasis (Rousseau et al. 2013). In fact, Rousseau et al. (2013) tested a low LPS concentration of $0,1 \mu \mathrm{g} / \mathrm{mL}$, and on this same concentration, we found that LPS increased tumor cells number. However, when we used higher concentrations of LPS we found a decrease in tumor cells number. One reason for this different effect might be due to TNF production; at high concentration, LPS could beinducing the production of a great amount of TNF, consequently being toxic to the cell, leading to cell death.

Yang et al. (2014) showed that activation of TLR4 might be related to tumor growth because it regulates the expression of mRNA for vascular endothelial growth factor (VEGF) in human breast cancer cells. The stimulation of TLR4 by LPS promoted tumor genesis and the development of metastatic lesions in the liver of mice (Yang et al. 2014).
There seems to be a connection between TLRs and esophageal cancer development. In fact, poor prognosis in strongly TLR-expressing tumors could be an indicator of increased level of tumorstroma interaction (Kauppila and Selander 2014). Barrett's esophagus (BAR-T cell line) were stimulated with the TLR4 agonist lipopolysaccharide (LPS).It was shown that stimulation of TLR4 with LPS resulted in NF- $\kappa B$ activation and an increase of IL-8 secretion (Verbeek et al. 2014). In fact, the structure of the LPS of Porphyromonasgingivalis (PgLPS) has a further particular antigenic moiety and is recognized by TLR2, which is responsible for the recognition of cell wall components of gram positive bacteria (Sipert et al. 2013).

Genetic studies have been performed on TLR polymorphisms in esophageal cancer. Unlike in gastric cancer, polymorphisms in TLR4 + 896A > $\mathrm{G}$ and TLR9-1237T/C genes were not associated to esophageal cancer risk (Kauppila and Selander 2014). However, genetic up-regulation of CD14, a co-receptor of TLR4, was observed in families with history of esophageal cancer (Kauppila and Selander 2014). This wound reaction could facilitate the passage of bacteria through epithelium and result in the loss of hostmicrobiome homeostasis, further leading to abnormal activation of for example TLR2, 4, 5, and 9 by bacterial components. Inflammation and wound reaction then could produce a vicious cycle of cellular damage, which might be a major player in esophageal metaplasia and carcinogenesis (Kauppila and Selander 2014).

In our study, we observed that the PgLPS at high concentrations has a tendency to increase cell viability in oral cancer cells (HN30). Taken together, our data demonstrated that LPS at high concentrations might contribute to tumor death, in agreement with previously data. Further studies will be carried out in order to verify the signaling pathway and receptors involved in the decrease of cell viability observed in human oral carcinoma after PgLPS treatment. In addition, TLR4 could be a future target to studies on human esophageal and oral tumors. 


\section{ACKNOWLEDGMENT}

The authors thankDrLuis Felipe Ribeiroand Dr Maria Martha Camposfor the donation of the cell lines, and the FINEP research grant "Implantação, Modernização e Qualificação de Estrutura de Pesquisa da PUCRS” (PUCRSINFRA) \# 01.11.0014-00.

\section{REFERENCES}

Almodova EC, Oliveira WK, Machado LFA, Grejo JR, Cunha TR, Colaiacovo W, et al. Atrophic gastritis: Risk factor for esophageal squamous cell carcinoma in a Latin-American population. World $J$ of Gastro. 2013; 19(13): 2060-2064.

Arantes V, Piñeros EAF, Yoshimura K, Toyonaga T. Advances in the management of early esophageal carcinoma. Rev Col Bras . 2012; 39(6): 534-543.

Chen JJ, Mikelis CM, Zhang Y, Gutkind JS, Zhang B. TRAIL induces apoptosis in oral squamous carcinoma cells - a crosstalk with oncogenic Ras regulated cell surface expression of death receptor 5. Oncotarget. 2013;4(2): 206-217.

Girardi FM, Zanella VG, Kroef RG. Correlation between clinical and pathological data and surgical margins in patients with squamous cell carcinoma of the oral cavity. Braz J of Otorhin. 2013; 79(2): 190195.

Gül N, Grewal S, Bögels M, Bij GJVD, Koppes MMA, Oosterling SJ et al. Macrophages mediate colon carcinoma cell adhesion in the rat liver after exposure to lipopolysaccharide. OncoImm. 2012; 1(9): 15171526.

Kauppila JH, Selander KS. Toll-Like Receptors in Esophageal Cancer. F Immun. 2014; 5(200).

Liu X, Pei C, Yan S, Liu G, LIU G, CHEN W et al.NADPH oxidase 1-dependent ROS is crucial for TLR4 signaling to promote tumor metastasis of nonsmall cell lung cancer. Tum Biol. 2015.

Ma Z, Guo W, Niu HJ, Yang F, Wang RW, Jiang YG, et al. Transcriptome Network Analysis Reveals Potential Candidate Genes for Esophageal Squamous Cell Carcinoma. Asian Pac J of Can Prev. 2012; 13: 763-773

Mota OM, Curado MP, Oliveira JC, Martins E, Cardoso DM. Risk factors for esophageal cancer in a lowincidence area of Brazil. São Paulo Med J. 2013; 131(1): 27-34.

Niu X, Wang Y, Li W, Mu Q, Li H, Yao $\mathrm{H}$ et al.Protective effects of Isofraxidin against lipopolysaccharide-induced acute lung injury in mice. Int Immunopharmacol. 2015; 24(2): 432-439.

Paleja B, Anand A, Chaukar D, D'cruz A, Chiplunkar $\mathrm{S}$. Decreased functional response to Toll like receptor ligands in patients with oral cancer. Hum Immun.
2013;

74(8):

927-936.

http:/www.ncbi.nlm.nih.gov/pubmed/23628388

Ren P, Zhang JG, Xiu L, Yu ZT. Clinical significance of phospholipase A2 group IIA (PLA2G2A) expression in primary resected esophageal squamous cell carcinoma. Eur Rev for $M$ and Pharmac Sci. 2013; 17: 752-757.

Romanini J, Mielcke TR, Leal PC, Figueiredo CP, Calixto JB, Morrone FB, et al. The role of CXCR2 chemokine receptors in the oral squamous cell carcinoma. Invest New Drugs. 2012; 30: 1371-1378.

Rousseau MC, Hsu RY, Spicer JD, Mcdonald B, Chan $\mathrm{CH}$, Perera RM, et al. Lipopolysaccharide-induced toll-like receptor 4 signaling enhances the migratory ability of human esophageal cancer cells in a selectindependent manner. Surgery. 2013; 154(1): 69-77.

Sipert CR, Morandini ACF, Modena KCS, Dionisio TJ, Machado MAAM, Oliveira SHP, et al. CCL3 and CXCL12 production in vitro by dental pulp fibroblasts from permanent and deciduous teeth stimulated by Porphyromonasgingivalis LPS. J Appl Oral Sci. 2013; 21(2): 99-105.

Steffen A, Huerta JM, Weiderpass E, Bueno de MHB, May AM, Siersema PD, et al. General and abdominal obesity and risk of esophageal and gastric adenocarcinoma in the European Prospective Investigation into Cancer and Nutrition (EPIC). Int J Cancer. 2015.

Sun Z, Luo Q, Ye D, Chen W, Chen F. Role of toll-like receptor 4 on the immune escape of human oral squamous cell carcinoma and resistance of cisplatininduced apoptosis. Mol Cancer. 2012; 11(33).

Tarapore RS, Yang Y, Katz JP. Restoring KLF5 in Esophageal Squamous Cell Cancer Activates the JNK Pathway Leading to Apoptosis and Reduced Cell Survival. Neoplasia. 2013; 15(5): 472-480.

Thakur B, Li H, Devkota M. Results of management of esophageal and GE junction malignancies in Nepalese contexto. $J$ of Thor Dis. 2013; 5(2): 123 128.

Toporcov TN, Biazevic MGH, Rotundo LDB, Andrade FP, Carvalho MB, Brasileiro RS, et al. Consumo de alimentos de origem animal e câncer de boca e orofaringe. R Panam Salud Pub. 2012; 32(3): 185 191.

Verbeek RE, Siersema PD, Ten KFJ, Fluiter K, Souza RF, Vleggaar FP, et al. Toll-like receptor 4 activation in Barrett's esophagus results in a strong increase in COX-2 expression. J Gastroen. 2014; 49: 1121-1134.

Vernooy J H, Dentener MA, Suylen RJV, Buurman WA, Wouters EFM. Intratracheal Instillation of Lipopolysaccharide in mice induces apoptosis in bronchial epitelial cells. A J of Resp Cell and Mol Bio. 2001; 24: 569-576.

Waal IVD. Are we able to reduce the mortality and morbidity of oral cancer; Some considerations. Med Oral Patol Oral Cir Bucal. 2013; 18(1): 33-37. 
Xu WW, Li B, Lam AKY, Tsao SW, Law SYK, Chan $\mathrm{KW}$, et al. Targeting VEGFR1- and VEGFR2expressing non-tumor cells is essential for esophageal cancer therapy. Oncotarget. 2014.

Yang H, Wang B, Wang T, Xu L, He C, Wen H, et al. Toll-Like Receptor 4 Prompts Human Breast Cancer Cells Invasiveness via Lipopolysaccharide Stimulation and Is Overexpressed in Patients with Lymph Node Metastasis. Plos One. 2014; 9(10).

Yang L, Francois F, Pei Z. Molecular pathways: pathogenesis and clinical implications of microbiome alteration in esophagitis and Barret esophagus. Clin Can Res. 2012; 18(8): 2138-2144.

Adeghate E, Ponery AS. Ghrelin stimulates insulin secretion from the pancreas of normal and diabetic rats. J Neuroendocrinol. 2002; 14(7): 555-560.

Asakawa A, Inui A, Kaga T, Yuzuriha H, Nagata T, Ueno $\mathrm{N}$, et al. Ghrelin is an appetite-stimulatory signal from stomach with structural resemblance to motilin. Gastroenterology. 2001; 120(2): 337-345.

Dagli AF, Aydin S, Karaoglu A, Akpolat N, Ozercan İH, Ozercan MR. Ghrelin expression in normal kidney tissue and renal carcinomas. Pathology Research and Practice. 2009; 205(3): 165-173.

Date Y, Nakazato M, Hashiguchi S, Dezaki K, Mondal MS, Hosoda H, et al. Ghrelin is present in pancreatic alpha-cells of humans and rats and stimulates insulin secretion. Diabetes. 2002; 51(1): 124-129.

Donder E, Dogan MM, Kuloglu T, Dabak ÖD, Kocaman N, Ozkan Y. The Investigation of the Effects of Enalapril and Losartan on Ghrelin Immunoreactivity in Kidney of StreptozotocinInduced Diabetic Rats. Firat Tip Dergisi. 2013; 18(1): 1-6.

Fujimura K, Wakino S, Minakuchi H, Hasegawa K, Hosoya K, Komatsu M, et al. Ghrelin protects against renal damages induced by angiotensin-II via an antioxidative stress mechanism in mice. PLoS One. 2014; 9(4): 94373.

Gnanapavan S, Kola B, Bustin SA, Morris DG, McGee $\mathrm{P}$, Fairclough $\mathrm{P}$, et al. The tissue distribution of the mRNA of ghrelin and subtypes of its receptor, GHSR, in humans. J Clin Endocrinol Metab. 2002; 87(6): 2988

Gohda T, Mima A, Moon J-Y, Kanasaki K. Combat Diabetic Nephropathy: From Pathogenesis to Treatment. Journal of Diabetes Research. 2014; 2014(1).

Gualillo O, Caminos J, Blanco M, Garcia-Caballero T, Kojima M, Kangawa K, et al. Ghrelin, a novel placental-derived hormone. Endocrinology. 2001; 142(2): 788-794.

Hewson AK, Dickson SL. Systemic administration of ghrelin induces Fos and Egr-1 proteins in the hypothalamic arcuate nucleus of fasted and fed rats. $J$ Neuroendocrinol. 2000; 12(11): 1047-1049.

Howard AD, Feighner SD, Cully DF, Arena JP, Liberator PA, Rosenblum CI, et al. A receptor in pituitary and hypothalamus that functions in growth hormone release. Science. 1996; 273(5277): 974-977.

Inui A. Ghrelin: an orexigenic and somatotrophic signal from the stomach. Nat Rev Neurosci. 2001; 2(8): 551-60.

Kageyama H, Funahashi H, Hirayama M, Takenoya F, Kita T, Kato S, et al. Morphological analysis of ghrelin and its receptor distribution in the rat pancreas. Regulatory Peptides. 2005; 126(1-2): 6771.

Kemp BA, Howell NL, Gray JT, Keller SR, Nass RM, Padia SH. Intrarenal ghrelin infusion stimulates distal nephron-dependent sodium reabsorption in normal rats. Hypertension. 2011; 57(3): 633-639.

Kojima M, Hosoda H, Date Y, Nakazato M, Matsuo H, Kangawa K. Ghrelin is a growth-hormone-releasing acylated peptide from stomach. Nature. 1999; 402(6762): 656-660.

Kojima M, Hosoda H, Matsuo H, Kangawa K. Ghrelin: discovery of the natural endogenous ligand for the growth hormone secretagogue receptor. Trends Endocrinol Metab. 2001; 12(3): 118-122.

Kuloglu T, Dabak DO. Determination of Ghrelin Immunoreactivity in Kidney Tissues of Diabetic Rats. Renal Failure. 2009; 31(7): 562-566.

Masaoka T, Suzuki H, Hosoda H, Ota T, Minegishi Y, Nagata $H$, et al. Enhanced plasma ghrelin levels in rats with streptozotocin-induced diabetes. FEBS Lett. 2003; 541(1-3): 64-68.

Mori K, Yoshimoto A, Takaya K, Hosoda K, Ariyasu $\mathrm{H}$, Yahata K, et al. Kidney produces a novel acylated peptide, ghrelin. FEBS Lett. 2000; 486(3): 213-216.

Muccioli G, Tschop M, Papotti M, Deghenghi R, Heiman M, Ghigo E. Neuroendocrine and peripheral activities of ghrelin: implications in metabolism and obesity. Eur J Pharmacol. 2002; 440(2-3): 235-524.

Nakazato M, Murakami N, Date Y, Kojima M, Matsuo $\mathrm{H}$, Kangawa K, et al. A role for ghrelin in the central regulation of feeding. Nature. 2001; 409(6817):194198.

Ozbek E. Induction of oxidative stress in kidney. Int $J$ Nephrol. 2012; 2012: 465897.

Pei XM, Yung BY, Yip SP, Chan LW, Wong CS, Ying $\mathrm{M}$, et al. Protective effects of desacyl ghrelin on diabetic cardiomyopathy. Acta Diabetol. 2014; 52(2): 293-306.

Rahimi R, Nikfar S, Larijani B, Abdollahi M. A review on the role of antioxidants in the management of diabetes and its complications. Biomedicine \& Pharmacotherapy. 2005; 59(7): 365-373.

Sonmez MF, Ozan E. Determination of ghrelin immunoreactivity in the rat stomach after fasting and refeeding. Acta Histochem. 2007; 109(3): 193-199.

Sun GX, Ding R, Li M, Guo Y, Fan LP, Yue LS, et al. Ghrelin attenuates renal fibrosis and inflammation of obstructive nephropathy. J Urol. 2014; 193(6): 2107 2115 . 
Tena-Sempere M, Barreiro ML, Gonzalez LC, Gaytan F, Zhang FP, Caminos JE, et al. Novel expression and functional role of ghrelin in rat testis. Endocrinology. 2002;143(2): 717-725.

Unsal F, Sonmez MF. The effects of ovariectomy on ghrelin expression in the rat uterus. Adv Clin Exp Med. 2014; 23(3): 363-370.

Venables G, Hunne B, Bron R, Cho H-J, Brock JA, Furness JB. Ghrelin receptors are expressed by distal tubules of the mouse kidney. Cell and Tissue Research. 2011; 346(1): 135-139.

Wang W, Bansal S, Falk S, Ljubanovic D, Schrier R. Ghrelin protects mice against endotoxemia-induced acute kidney injury. Am J Physiol Renal Physiol. 2009; 297(4): 1032-1037.

Wren AM, Small CJ, Ward HL, Murphy KG, Dakin $\mathrm{CL}$, Taheri S, et al. The novel hypothalamic peptide ghrelin stimulates food intake and growth hormone secretion. Endocrinology. 2000; 141(11): 4325-4328.
Yabuki A, Taharaguchi S, Ichii O, Kojima M, Nishi Y, Mifune $\mathrm{H}$, et al. Immunohistochemical localization of ghrelin in rodent kidneys. Histochem Cell Biol. 2006;126(2): 231-238.

Yin Y, Li Y, Zhang W. The Growth Hormone Secretagogue Receptor: Its Intracellular Signaling and Regulation. International Journal of Molecular Sciences. 2014;15(3): 4837-4855.

Yoshimoto A, Mori K, Sugawara A, Mukoyama M, Yahata K, Suganami T, et al. Plasma Ghrelin and Desacyl Ghrelin Concentrations in Renal Failure. Journal of the American Society of Nephrology. 2002; 13(11): 2748-2752.

Yuan MJ, Huang H, Huang CX. Potential new role of the GHSR-1a-mediated signaling pathway in cardiac remodeling after myocardial infarction (Review). Oncology Letters. 2014; 8(3): 969-971.

Received: September 01, 2015; Accepted: January11, 2016. 


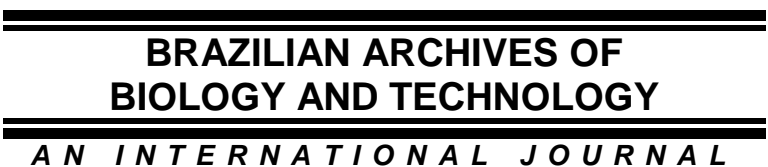

\section{Erratum}

In Article "Effect of LPS on the Viability and Proliferation of Human Oral and Esophageal Cancer Cell Lines", with the number of DOI:http://dx.doi.org/10.1590/1678-43242016150485 , published in journal Brazilian Archives of Biology and Technology, vol. 59, the 01 page.

that read:

"Márcia Gonçalves ${ }^{1}$, Angélica Regina Cappellari ${ }^{1}$, André Avelino dos Santos Junior , Fernanda Souza Macchi ${ }^{1}$, Krist Helen Antunes ${ }^{2}$, Ana Paula Duarte de Souza ${ }^{2}$, Fernanda Bueno Morrone ${ }^{1}$, Fernanda Olicheski Marchi ${ }^{1}$

${ }^{1}$ Pontifícia Universidade Católica do Rio Grande do Sul, Faculdade de Farmácia, PUCRS, Brasil . "Instituto de Pesquisa Biomédicas,"

Read:

"Márcia Gonçalves ${ }^{1}$, Angélica Regina Cappellari ${ }^{1}$, André Avelino dos Santos Junior", Fernanda Olicheski de Marchi ${ }^{1}$, Fernanda Souza Macchi ${ }^{1}$, Krist Helen Antunes ${ }^{2}$, Ana Paula Duarte de Souza ${ }^{2}$, Fernanda Bueno Morrone ${ }^{1}$

${ }^{1}$ Pontifícia Universidade Católica do Rio Grande do Sul, Faculdade de Farmácia, PUCRS, Brasil . Instituto de Pesquisas Biomédicas;"

In Article "Effect of LPS on the Viability and Proliferation of Human Oral and Esophageal Cancer Cell Lines", with the number of DOI:http://dx.doi.org/10.1590/1678-43242016150485, published in journal Brazilian Archives of Biology and Technology, vol. 59, the 07 page.

That read:

"The authorsthankDrLuis Felipe Ribeiro andDr Maria Martha Camposforthedonationofthecelllines, andthe FINEP researchgrant "Implantação, Modernização e Qualificação de Estrutura de Pesquisa da PUCRS” (PUCRSINFRA) \# 01.11.0014-00"

Read:

"The authors thank Dr Luis Felipe Ribeiro and Dr Maria Martha Campos for the donation of the cell lines, and the FINEP research grant "Implantação, Modernização e Qualificação de Estrutura de Pesquisa da PUCRS” (PUCRSINFRA) \# 01.11.0014-00” 